DOI https://doi.org/10.36059/978-966-397-178-0/121-142

\title{
CRIME IN EPISTEMOLOGICAL-AXIOLOGICAL CONTEXT PARADIGMS OF QUALIFICATION AND COMPOSITION
}

Klyuev O. M.

\section{INTRODUCTION}

The criminal code of Ukraine, which entered into force on September 1, 2001 , opened a new page in the history of domestic criminal law. Sixteen years is a sufficient period to sum up some results, to comprehend the way that science and practice have passed during this time in the application of the Criminal code.

The introduction of the criminal law covers multifaceted activities of state law enforcement agencies related to various issues, namely: criminal-legal assessment of the offense; sentencing proceedings; exemption from punishment and serving it; the application of compulsory measures of a medical nature.

Criminal-legal assessment of the offense consists of two components-the separation of criminal from non-criminal and the qualification of the crime. In practice, both components are as if one whole, and in theory they are different and are considered separately. The axiological concept of this approach is that the recognition of the offense as non-criminal eliminates the need to solve all other issues of criminal law and, conversely, if criminal causes such a need, and the qualification of the crime comes to the fore, that is, the establishment of compliance with the latter signs of a specific crime. Qualification of crimes is the basis for the imposition of punishment, exemption from criminal liability and punishment, and the like. And at the same time it allows to state that qualification of crimes makes the Central core of application of the criminal law in investigative and judicial practice. And here it should be noted that the implementation of the qualification of crimes by all law enforcement agencies and the court characterizes its activities as such that unites these bodies and the court with the same tasks and responsibilities, which ultimately binds them.

During the qualification of crimes there are numerous epistemological problems of criminal law in their various combinations, you are the problems and vulnerabilities of criminal law, theoretical concepts and the like. Here it is important to distinguish between the theoretical provisions of the qualification of crimes, or the theory of qualification of crimes, on the one hand, and the qualification of crimes in practice by investigators and judges, on the other. Theoretical positions reflect qualification of types of crimes within their 
description in criminal law norms. With regard to practical actions, it takes into account all, without exception, established and proven factual circumstances of the act in its personal manifestation. These distinctions show that the pure theory of qualification of crimes cannot recommend "ready recipes" of each separate crime because it is simply impossible to consider all nuances of the crime committed in various life situations. The theory of qualification of crimes will establish a fundamental scientific basis for criminal and legal assessment of criminal acts.

And today, when Ukraine is developing a legal state, the exact qualification of the crime in practice is one of the most important influences of such development not in words, but in reality.

This indicates the relevance of the proposed monograph and the author's forecast of a certain interest in it from practitioners and scientists, graduate students and students of higher law schools.

So, it can be stated that the composition of the crime is a legal basis for the qualification of the crime. Let us pay attention to the epistemological gap, because in the criminal law there is such a thing as" the composition of the crime", and the concept of "qualification of the crime" is not. By the way, their content in the criminal law is not defined. It is revealed in the theory of criminal law. As you can see, the theoretical provisions are the basis for the application of criminal law, namely: the qualification of crimes in the investigator and judicial practice.

\section{Qualification of crimes: epistemology, axiology, status}

1.1. Epistemological context of the qualification of the crime

In modern scientific legal literature, the issue of qualification of crimes is given considerable attention. In particular, in the textbook on criminal law of Ukraine edited by professors V. Stashis and V. Tation qualification of crimes is defined as the exact establishment of a socially dangerous act committed by the perpetrator of a specific crime, enshrined in the criminal law. Some authors interpret the qualification of crimes as "the establishment and legal consolidation of the exact responsibility between the signs of the committed act and the signs of the corpus delict provided for in the criminal law norm"1. Both definitions can be taken as a basis for a detailed disclosure of the content of the concept of "qualification of crimes".

In our opinion, this concept consists of four parts. The first determines that the qualification of the crime is an assessment of a criminal act, that is, an act that has all the signs of a crime under the criminal code of Ukraine.

\footnotetext{
${ }^{1}$ Kudryavtsev V. the General theory of qualification of pre-steps. Moscow: Yuridicheskaya Literatura, 1972. P. 8;
} 
If, assessing the act, the employee of the law enforcement Agency comes to the conclusion that it is not criminal, then the qualification of the action or inaction as a crime is excluded. It should be borne in mind that the qualification of crimes is a subjective category. Therefore, it is necessary that the person who gives a legal assessment of the offense, had, first, knowledge of criminal law, and secondly, the skills, on the one hand, to identify the signs of the committed act, and on the other - to compare the latter with the signs of the crimes provided for in the criminal code of Ukraine, as well as clearly adhere to the laws of logic, which make it possible to establish whether or not both coincide. As a consequence, it can be stated that the speed of qualification of crimes depends on the knowledge of the subject of criminal law and the level of his abilities.

The second part of the qualification of the crime is the signs of the committed act. In practice, these signs are reflected in criminal cases. They can also be used in the educational process as practical tasks in criminal law, and in the literature-in the coverage of criminal acts that have taken place or are fictional authors of crimes.

In practice definition of the specified signs are established by their analysis by the subject during which these signs are separated from others, are concretized and detailed.

The third part of the qualification of the crime, as already noted, is a comparison of the identified signs of the crime with the signs of the relevant article of the criminal code of Ukraine. Both scientists and practitioners call this part "signs of a crime, which characterize the objective side of a specific article of the criminal code of Ukraine and separate one crime from another. But it should be borne in mind that the signs of a crime are provided not only in the dispositions of articles of the General and Special part of the criminal code of Ukraine, but also in other legal acts, references to which are made in the blank dispositions of articles of the Special part of the criminal code of Ukraine.

The fourth part of qualification of crimes assumes establishment and legal fixing of exact correspondence between the signs given by us in the second and third parts. Such establishment consists in comparison of actual signs of the committed act with signs of concrete structure of a crime and a statement in case of coincidence of their identity.

Further the received conclusions concerning the guilty person are fixed or in the resolution on attraction to criminal responsibility, the indictment or in the sentence. That is, it is indicated that the actual signs of the committed act exactly correspond to the signs of a specific crime.

Therefore, qualification of crimes should be defined as establishment and legal fixing of exact correspondence between the actual signs of the 
committed and signs of structure of the crime provided by the criminal law and other laws and normative-legal acts encroachment on which are fixed in blank dispositions of articles of a Special part of UK of Ukraine.

Concerning practical workers, they under qualification of crimes understand establishment in the committed act of signs of the corresponding structure of the crime provided by article of the criminal code of Ukraine.

As you can see, the qualification of crimes, on the one hand, is a process, and on the other - the result. How the process will take place, firstly, the identification of the actual signs of the committed act, and secondly, the choice of criminal law, that is, the article of the Special part of the criminal code of Ukraine, and in the case of the latter-other laws or regulations to which there are references. And, at last, the last is a study of actions of the subject of qualification of crimes in their comparison. However, it should be noted that such a process is divided into these components only theoretically. In fact, in the thoughts of the practical worker, that is, the subject of the qualification of crimes, all these parts complement each other and are organically interconnected, and the whole process takes place as a whole. In other words, the conclusion that the factual characteristics of the offense correspond to the elements of a crime under the criminal code of Ukraine, and if the provisions of this article blanket, and even other laws or regulatory acts referenced in the specified disposition. At the same time, such consolidation occurs, as already noted, in the prepared document, where the signs of the committed act are fixed, provided for in a specific article of the Special part of the criminal code of Ukraine. And here practitioners should bear in mind that in this case, in order to reduce the registration of the offense, neither articles of the General part of the criminal code (except for cases of unfinished crime and complicity in it) nor other laws and regulations to which references are made in the article of the Special part of the criminal code of Ukraine, if its disposition is blank.

Some of the scholars and practitioners may object and say that a large number of circumstances and facts accompanies each crime. We believe that not all of these facts have criminal and legal significance, i.e. not all affect crime and its punishment. For example, the time of the offense is essential to prove the crime, however, from the point of view of criminal law for offences not affected. Thus, it can be stated that the establishment of the actual circumstances of the case corresponds to the legal norm, forms a certain crime, in its logical form-deductive syllogism. It established the actual circumstances are recorded in a smaller volume.

However, the qualification process as a whole can be reduced only to deduction, the achievement of truth is impossible without the relationship of deduction and induction, since the establishment of the actual circumstances 
of the criminal case, as well as the accumulation of various facts, occurs mainly by inductive means.

In the legal literature two types of qualification of crimes are considered: official (legal) and informal (doctrinal $)^{2}$.

The official (legal) qualification of crimes is the criminal-legal qualification carried out on a specific criminal case by a person authorized by the state, namely: an investigator, a Prosecutor, a judge, etc.

Unofficial (doctrinal) qualification of crimes is their legal assessment, which is carried out by individual citizens, including researchers, authors of articles, monographs, textbooks, manuals.

In our opinion, the unofficial qualification of the crime is not qualitatively the same and its content can be divided into two parts. To the first belongs the main informal part of the qualification of the crime, which is provided, as indicated above, by citizens. However, their qualification of a criminal act, as a rule, does not have any sign that the official qualification of the crime has. Therefore, this part should be called-unofficial qualification of crimes.

The second part of definition of informal qualification of crimes which, on the one hand, is given by participants of criminal process, that is accused, the defender, the victim, the suspect, the civil claimant and another in the statements from concrete criminal case, and with another - Plenum of the Supreme Court of Ukraine is of certain interest. As a rule, the content of the definition of the qualification of the crime is different.

It should be noted that the division of the qualification of the crime into official and unofficial is not related to the accuracy of the qualifications of the crime. Sometimes the unofficial qualification of the crime can be correct.

We will note that scientists consider qualification of a crime mainly concerning separate types of crimes (against property, bases of national security of Ukraine, against life and health of the person, etc.) which concern a Special part of criminal law of Ukraine.

\subsection{Axiology of crime qualification}

The value of qualification of crimes is multifaceted. It has a General social and criminal-legal character. General social value of qualification of crimes describes the state of the socio-legal system, on the one hand, is the Foundation of the rule of law in the state, on the other - occupies a Central place in formation of legal state in Ukraine. In General, the observance of the rule of law in the state, its provision is evidenced, first of all, by the extent to which repression is applied in accordance with the criminal law in General

${ }^{2}$ Kurinov B. Scientific bases of qualification of crimes. Moscow: Moscow state University, 1984. P. 20. 
and how objectively the qualification of committed socially dangerous acts in particular is controlled.

To assess the formation of the rule of law can be two parameters. The first is the content and form of the law, especially the criminal law. The meaning of the law is to what extent the state will, which, in fact, expresses the will of the bureaucracy, which is at the head of power, as well as large capital, corresponds to the will of the citizens of Ukraine; how justified are taken under the protection of the law public relations as the most important and valuable in the state; how the state reacts to crimes, that is, socially dangerous acts; as a matter of fact, and not declaratively, the crimes are differentiated by the degree of public danger reflected in the sanctions of the articles of the Special part of the criminal code of Ukraine.

As already noted, the criminal-legal significance of the qualification of crimes is multifaceted and appears in several cases. Distinguishing main and prominent ones, it is necessary to note that correct and accurate qualification of crimes is:

a) the enforcement of the law when administering justice;

b) reflection of socio-political and legal assessment of the offense;

c) the safeguarding of the rights and legitimate interests of the perpetrator and the promotion of individualization of criminal liability and punishment in accordance with regulations of the criminal code of Ukraine;

d) determination of possibilities of application of Institute of release from criminal responsibility and repayment of criminal record;

e) ensuring an order of investigation of crimes according to the CPC of Ukraine;

f) possibility of providing the correct characteristic of a condition, structure and dynamics of crime, and also development of effective measures of fight against it.

The above qualification of crimes will ensure compliance by law enforcement agencies, Executive authorities and the court with the constitutional principle of legality and the principles that follow from it.

The General situation, which vividly displayed the criminally-legal value of accurate classification of crimes is a provision contained in part 1 of article 2 of the criminal code, which provides that "the basis of criminal liability is any person committing a socially dangerous act which constitutes a crime under this Code" $"$.

The exact qualification of a crime is guaranteed the rights and legitimate interests of the perpetrator of the subject through individualization of criminal liability and punishment, and consequences that emerge as they implement the

${ }^{3}$ Ukrainian criminal code. Sumy: LLC "GDP Nostis”, 2015. 
article of the Special part of the criminal code that corresponds to the offense act, regulations of the General part of the criminal code regulating the possibility of bringing to criminal liability for preparation for a crime, sentencing, taking into account the degree of public safety not crime and of the perpetrator, and the like.

Taking into account the above, it can be argued that the correct qualification of the crime is important in criminology, since on its basis the qualitative structure of crime is highlighted and the necessary measures for its prevention are developed. If the qualification of crimes is wrong, it will give the wrong picture of the state and dynamics of crime, which, in turn, will lead to errors in the planning of preventive work. It should also be noted that the qualification of crimes has a certain importance in law enforcement, because the success or difficulties in qualification provide the legislator with information about the degree of law enforcement effectiveness of certain criminal law norms and can be the basis for making the necessary changes and additions to them ${ }^{4}$.

\subsection{The status of the crime in the system of offenses}

It is known that crimes are the most socially dangerous type of offenses. Encroachment on protected public relations, for example, encroachment on the life and health of a person, on sexual freedom and sexual inviolability, on the foundations of the constitutional system and others, as a rule, are criminal. However, there are many objects, attacks on which can be crimes and other offenses-civil delicts, administrative or disciplinary offenses. Therefore, it is very important to be able to separate the crime from other offenses, the responsibility for which is regulated in administrative, economic, tax, financial law and the like.

Crimes and non-crime offenses are distinguished by three main criteria: object; public danger; type of illegality.

From the stated follows that objects of crimes are interests which in other branches of the law are not present owing to their special value (for example, objects of crimes against bases of the constitutional system of Ukraine).

The closest to the criminal legislation on the diversity of protected interests is the Code of Ukraine on administrative offences (CAO) $)^{5}$. In accordance with article. 9 administrative Code administrative offense (misdemeanor) recognized illegal, guilty (intentional or careless) action or

\footnotetext{
${ }^{4}$ Sukhonos V. Criminal law of Ukraine. General part: textbook / V. V. Sukhonos . Sumy: University book, 2016. P. 46-55.

${ }^{5}$ Code of Ukraine on administrative offences. URL.: http://zakon3.rada.gov.ua/laws/show / 80731-10.
} 
omission, encroaching on public order, property, rights and freedoms of citizens, the established order of management and for which the law provides for administrative responsibility. The subject of its regulation is the dignity of man and citizen, sanitary and epidemiological safety of the population.

With regard to public danger, it is and remains an exceptional sign of crime. Despite the fact that incessant offenses are also to some extent negative, and their nature and degree of antisocialist never reach the level of criminal situation, which in criminal law has the name of public danger. And although some crimes at first glance, and resemble administrative offenses, but always cause more harm, their guilt is anti-social, criminal motives, and methods of committing more socially dangerous. Practice shows that the legislator and the courts in the interpretation of the rule of law always try as accurately as possible to distinguish between crimes and offenses. First, attention is drawn to the amount of harm caused to a person, society, the state. Material damage is confirmed in formal terms, and physical-in clearly fixed indicators of disability, organs or their functions (Art. 121-128 of the criminal code of Ukraine). In war crimes, to distinguish the crime from other disciplinary offenses of the criminal code of Ukraine as a sign calls the time, circumstances, place of Commission of the crime. For example, unauthorized abandonment of a military unit or place of service is qualified under part 1 of article 407 of the criminal code of Ukraine, if the subject did not appear after three dobi7, and up to three days - it will be a disciplinary offense.

If we take the subjective side of the crime, the law most often draws attention to the purpose, motive and form of guilt in General, distinguishing the crime from the non-criminal offense. For example, intentional slight bodily injury (Art. 125 of the criminal code) is a crime, and careless-a misdemeanor ${ }^{6}$.

A clear distinguishing feature is the type of illegality. Crime is always prohibited by criminal law under threat of punishment. Non-criminal offences are regulated by other branches of law, as already noted.

The difference between crime and offense applies to sanctions. For crimes comes criminal responsibility more strict, than measures disciplinary, economic, labor influence.

The need to distinguish between crimes and disciplinary offenses usually arises in the Commission of official and military crimes. Practice shows that quite often for disciplinary offenses hides a crime, including for violation of safety regulations. It should also be borne in mind that crime is always an act, and immoral acts can manifest themselves not only in command, but also in a way of thinking or speaking, and they are always less anti - social. As a rule,

\footnotetext{
${ }^{6}$ Ukrainian criminal code. Source: LLC “GDP NOTIS”, 2015. P. 55.
} 
the damage from them has a socio-psychological content: humiliation of honor and dignity of the person, etc. I would like to note that a clear distinction between crimes and immoral offenses takes place on the basis of illegality. If crimes are prohibited by criminal law, then immoral offenses are not regulated by legal norms at all. Norms of dignity can be written and oral (e.g. customs). The first include the Hippocratic oath-the code of medical ethics, the code of officer honor, the ethical code of journalists.

It is also necessary to take into account the requirements of part 1 of article 11 of the criminal code of Ukraine, which clearly fixed three signs of crimes: predictability in the laws on criminal responsibility, public danger of the act and guilt. The first-the predictability of the act of the criminal code of Ukraine - is formal, which reflects the illegality. Other signs-public danger and guilt-are material, revealing the socio-psychological nature of the crime.

However, part 2 of article 11 of the criminal code of Ukraine directly indicates that "it is not a crime to act or omission, which, although formally and contains signs of any act provided for by this Code, but through insignificance does not pose a public danger, that is, did not cause and could not cause significant harm to a natural or legal person, society or the state"7.

In order to apply part 2 of article 11 of the criminal code of Ukraine should, as noted above, to establish, first, the presence of crime the bottom surface of the formal criteria of an act which provided for in the criminal code, that is, all those objective subjective criteria that in the appropriate article of the Special part of the criminal code to characterize a certain crime. For example, if the abuse of power or official position (part 1 of art. 364 of the criminal code of Ukraine) there is no significant harm to the protected rights, freedoms and interests of individual citizens or the state or public interests, or the interests of legal entities, and it was not aimed at causing such harm, such abuse does not fall under part 2 of article 11 of the criminal code of Ukraine, because it does not Such an act does not refer to crimes, but to official misconduct. Secondly, it is necessary to recognize the acts such that only formally contains the signs of the act provided for by the criminal code of Ukraine. That is, it does not contain the public danger that is typical of the crime, and therefore is considered insignificant. Thirdly, it is necessary to take into account the subjective characteristic of a minor act: it objectively not only did not cause harm, but also subjectively was not aimed at causing significant, substantial harm. Only the totality of these conditions makes it possible to define the acts as insignificant, that is, not a crime.

Proceeding from the stated, we can state that crimes from non-criminal offenses and immoral offenses differ on the General object, wider and various,

\footnotetext{
${ }^{7}$ Ukrainian criminal code. Sumy: LLC “GDP Nostis”, 2015. P. 9.
} 
than in other branches of the right; anti-social system which in crimes is the highest, and is called "public not safety".

The basis of the distinction in the most public danger is harm, because the interests of citizens, society and the state are protected by law. Among other signs it is possible to define direct intention, motivation, socially dangerous actions, in particular group, with use of official position or the weapon.

It should be remembered that in criminal law it is reasonably recognized that public danger is the criterion that should be the basis for distinguishing crime from other offenses. However, there is no unity among scientists on the question of how exactly it performs this differentiating function.

\section{Corpus delicti: epistemological and axiological contexts}

\subsection{The composition of the crime in the epistemological context}

The definition of crime (both legal and doctrinal) indicates the legal and social characteristics inherent in the latter. These features (illegality, public danger, guilt and punishability) make it possible to separate the criminal act from other offenses and acts that are not a crime. Qualification of crimes, if they are defined in the most General form as a result, is the fixation of the identity of the signs of the actually committed socially dangerous act to the signs of the corpus delicts. Therefore, in order to distinguish from the total number of criminal acts a certain crime (for example, theft or murder, robbery or desertion) and there is a special concept of the crime. This gives grounds to argue that the study of the crime is the main core of the theory of criminal law.

In the study of crime examines some of the defining provisions of the General part of criminal law of Ukraine, which, on the one hand, the basis of specific offences and is the subject of his Particular part, and on the other specify a connection terminal of the latter. In the theory of criminal law, the corpus delicts is defined as a set or system of objective and subjective features that, in accordance with the criminal law, characterize a socially dangerous act as a crime ${ }^{8}$.

The composition of the crime received this name precisely because it consists of several parts that have the name of elements of the crime. It is known that four elements belong to the composition of the crime, which in their totality form an interconnected system and are in the composition of the evil in a specific sequence, that is, each element has its pre-assigned place. This rigid sequence is due to the specificity of each element and the relationship between them. The elements of the crime are: the object of the

\footnotetext{
${ }^{8}$ Halabala M. Criminal-legal science of independent Ukraine. Problems of the General part: the textbook / M. Halabala. Kyiv: Yurinkom Inter, 2013. P. 37-74.
} 
crime; the objective side of the crime (the crime); the subject of the crime; the subjective side of the crime (corpus delicts).

Therefore, the full structure of a crime have to be all four elements. The absence of at least one of them determines the absence of the crime as a whole. This gives the right to argue that in fact the criminal law and its application in practice indicate that each element of the crime should be specific. It consists that as a part of a crime the set of the signs characterizing its elements and structure as a whole which are inherent, according to the criminal law, to a concrete type of a crime contains ${ }^{9}$. In other words, the composition of the crime should be understood as a homogeneous group of legal features that characterize the crime from one side, for example, the composition of murder, theft, robbery, banditry and the like. In a particular crime, the General features inherent in this particular type of crime must be accumulated, which are revealed in each individual act of this type. At the same time, in case of manifestation of many separate acts as signs of the structure of crime General for this type in the criminal law those which, first, repeat in any separate act of a concrete type, secondly, are essential, and, thirdly, characterize their public danger are recognized.

Specific elements of crimes and their signs are provided in the criminal law-articles of special and General parts of the criminal code of Ukraine. They can also be defined in other laws or regulations, references to which are in many blank dispositions of articles of the Special part of the criminal code of Ukraine.

If you go deeper into the theory of criminal law, it should be noted that in the General understanding of the composition of the crime reflects the laws of construction of any particular crime and its elements, as well as concentrated the concept of all, without exception, the elements and features inherent in all specific crimes, and the signs manifested in individual crimes. This concept is the theoretical basis for the knowledge of specific elements of crimes in their concretized sense, ordered, systematic form. A common understanding of the crime and its contents are the result of using the scientific method of movement from abstract to concrete thinking, regardless of documented application of this method in the minds of builder this concept or not.

It can be argued that the correct qualification of crimes is impossible without the presentation of the composition and content of the relevant legal norms, that is, without their interpretation. Indeed, if the crime itself is a socially dangerous act of a person, then after carrying out certain work from the General to the private, we can argue that there are signs of a crime, and

9 Criminal law. General part: the textbook/ OTV. edited by I. Kozachenko and Z. Neznamova. Moscow: Norma, 1997. P. 114. 
this is a legal understanding defined in the criminal law. It should be remembered that the number of signs of the crime and the composition of the crime is heterogeneous, because the latter always has a set of typed signs and its volume indicates a specific crime, that is, in fact, is a crime. And since the composition of the crime always covers not the actual socially dangerous act, but all such acts of a certain kind, it differs from each crime. If a specific composition is a legal concept of a certain kind, then the General concept of composition is the concept of the structure and characteristics of all specific compositions of crimes. It summarizes the features that characterize the object, the objective side, the subject, the subjective side of all crimes, which is in the criminal legislation. And, therefore, these common signs and there is ostensibly a theoretical Foundation for the study of specific crimes. It should be understood that the General and specific crimes have different purposes.

The concrete structure of a crime is definition in the criminal law of a crime of a certain type, and therefore if in act of the person all signs of a concrete structure of a crime are established, it is the basis for criminal responsibility.

Depending on the General understanding of the crime in the theory of criminal law distinguish its generic and species composition. The first is a generalized characteristic of homogeneous crimes having a set of features inherent only in these crimes. Homogeneous crimes in the current Criminal code of Ukraine are in one section of its Special part, for example, Section II "crimes against life and health of the person"10. In addition, here it should be remembered that the generic composition covers the General characteristic of the species composition of this. The specific structure of a crime is the characteristic of separate types of the crimes United on the General sample in one Chapter of the corresponding section of the criminal code of Ukraine. For example, sections III, IV, V, etc ${ }^{11}$.

It is important to understand that the composition of the crime - a real system of signs, and not the fruit of human imagination. And if it is an objective reality, then it can be known and used in practical activities. This makes it possible to assert that reflected and detailed in the consciousness of the practical worker the content of each specific crime, its elements and features provides an opportunity to compare: a) this crime, its elements and features; b) actually committed socially dangerous act and its features.

It is also important to determine the relationship between the concepts of "crime" and "corpus delicti". These concepts are interrelated, but not

\footnotetext{
${ }^{10}$ Criminal law, General part, textbook ed. Kharkiv: Pravo, 2010. P. 85.

${ }^{11}$ Gonchar T., Streltsov, E., and such famous O. Criminal law of Ukraine. General and special parts 6 tutorial. Kharkiv: Odyssey, 2013. P. 29.
} 
identical. First, the concept of crime is characterized by four characteristics, namely: public danger, illegality, guilt and punishability. The concept of corpus delicti is also characterized by four, but not signs, but elements, which, as noted above, include the object, the objective side, the subject and the subjective side. Secondly, the concept of corpus delicti does not include such a feature of the crime as punishability. Thirdly, the concept of crime separates all criminal from all non-criminal, and the concept of crime defines each type of crime and separates it from others, which affects the legal assessment of the offense. Fourth, the concept of crime reflects the social and legal essence of any crime, and the concept of the crime-its legal structure. In addition, the concept of crime and the specific elements of crimes are defined in the criminal law. Thus, the concept of crime is defined in article 11 of the criminal code of Ukraine, and the specific crimes in the articles of the Special part and V. 18-49 of the General part of the criminal code of Ukraine, as well as, as already noted, other laws and regulations to which there are references in the blank dispositions of the special part of the criminal code of Ukraine.

It should be remembered that each element of the crime is characterized by features that are defined in the criminal law. In the General understanding of the corpus delicti, the objective and subjective features that characterize it are divided into mandatory, including alternative, and optional. Obligatory signs are such signs which presence is necessary in any structure of a crime, and absence at least one of them excludes existence of structure of a crime.

Optional are the features that are in each part of the crime: in some parts of the crime they are provided for and are mandatory for these parts, and in others-not.

Each element in the General understanding of the crime is characterized by mandatory and optional features. Thus, the object of the crime has one mandatory feature-that is, the object and two optional features: 1) the subject of the crime and 2) the victim of the crime.

The objective side of the crime is characterized by a mandatory feature-the act and eight optional features: 1) consequences; 2) causal relationship between the act and the consequences; 3) place; time; 5) circumstances (conditions); 6) method; 7) tools and 8) means of committing a crime.

It should be noted that the consequences and the causal relationship between the act and the consequences are an optional feature of all crimes and at the same time mandatory for crimes with a material composition.

As for the subject of the crime, it has three mandatory and one optional feature. Mandatory are: a natural person (article 18 of the criminal code of Ukraine); a sane person (article 19 of the criminal code of Ukraine); a person who has reached the age of criminal responsibility (article 22 of the criminal code of Ukraine). 
Optional is provided by the criminal law in addition to the above feature that characterizes the characteristics of the subject of the crime, that is, "special subject of the crime".

The subjective side of the crime is the inner side of the crime, which reveals the mental processes that characterize the consciousness and will of the person at the time of the crime. It has one mandatory feature, which is guilt and two optional features, which include: a) motive And b) purpose.

\subsection{Criminal law and corpus delicti}

It is known that the basis of the qualification of the crime is a specific crime, provided by the disposition of the relevant article of the Criminal code of Ukraine. The concrete structure of a crime is defined in the criminal law not as a certain whole, and in the form of its signs. A sign of a crime is a concept expressed in a criminal law by one term or several, as well as, in some cases, in another law and/or other normative act or international Treaty. It should be borne in mind that the signs of a crime from the standpoint of their definition in the criminal law can be classified according to some criteria. After the mandatory and optional features are: normative origin; criminal-legal significance; degree of public danger; epistemological essence; certainty; degree of permanence; specificity of criminal description in the law.

Let's analyze some of them. So, based on such criterion as a normative source, the signs of a crime envisaged in the first article of the Special part of the criminal code, which establishes liability for the crime; secondly, in the titles of the sections of the criminal code of Ukraine; thirdly, to articles of the General part of the criminal code of Ukraine; fourth, in the other (noncriminal) laws or other legal acts of Ukraine, are referenced in the blanket the dispositions of articles of the Special part of criminal code of Ukraine, fifth, in the international treaties of Ukraine, which also has a link.

In the disposition of the articles of the Special part of the criminal code of Ukraine, the signs that individualize a specific crime are determined, and also separate this composition from other crime compositions, while always all these signs belong to the objective side, and if they are present, there are all optional signs.

In addition, the dispositions of some articles of the criminal code provides for individual features that characterize the object of the crime (for example, in part 1 of article 296 of the criminal code of Ukraine), the subject of the crime (e.g. art. 364, 364-1, 365, 365-2, 368) and a subjective side (separately in article 115, 119 and in many other articles of the criminal code of Ukraine). It should be noted that the signs of the objective side of the specific corpus delicti are provided only in the dispositions of the articles of the Special part of the criminal code of Ukraine. 
In the names of sections of the criminal code of Ukraine are defined, we can say, typical, as well as generic objects of crimes, for example, in the name of the second section to such an object can be attributed to a person, and to the generic object-his life and health.

With regard to the norms of the General part of the criminal code of Ukraine, they contain, first, signs common to all or many crimes, characterizing their object and subjective side; secondly, signs inherent in the unfinished crime (preparation, attempt) and the composition of the crime against its perpetrators (organizer, instigator and accomplice, article 27 of the criminal code of Ukraine), and thirdly, signs, the presence of which excludes the crime as such. For example, in part 1 art. 1 of the criminal code specifies certain objects that are protected by law: legal protection of the rights and freedoms of man and citizen, property, public order and public security, environment, the constitutional system of Ukraine from criminal encroachments, peace and security of mankind ${ }^{12}$. However, this list is not exhaustive, the final version is listed in the sections of the criminal code of Ukraine.

The subject of a crime is defined in part 1 of article 18 of the criminal code of Ukraine, and in article 19, 20, 22 of the criminal code of Ukraine such its signs as sanity, age, limited sanity are concretized.

In Art. 23 of the criminal code of Ukraine certain wines and its forms, and in Art. 24, 25 of the criminal code of Ukraine these forms are specified. Part 2 of article 13 of the criminal code of Ukraine contains the definition of an unfinished crime, and articles 14 and 15 of the criminal code of Ukraine specify its stages.

Article 26 of the criminal code of Ukraine defines the concept of complicity, the content of which is disclosed in articles 27, 28, 29 of the criminal code of Ukraine. It should be noted that it is in these articles that the signs of a crime in the acts of accomplices who are not its perpetrators are reflected and enshrined in the articles of the Special part of the criminal code, but act as an organizer, instigator or accomplice. As already noted, the General part of the criminal code contains rules that exclude the criminality of the act and, accordingly, the composition of the crime. These include the signs provided for in part 2 of article 11 of the criminal code of Ukraine, part 2 of article 22 of the criminal code of Ukraine, part 2 of article 31 of the criminal code of Ukraine, art. 36-43 criminal code of Ukraine.

As already noted, according to part 2 of article 11 of the criminal code, "it is not a crime to act or omission, which, although formally and contains

\footnotetext{
${ }^{12}$ Sukhonos V. Criminal law of Ukraine. General part: textbook / V. V. Sukhonos. Sumy: University book, 2016. P. 59-65.
} 
signs of any act provided for by this Code, but through insignificance does not pose a public danger, that is, did not cause and could not cause significant harm to a natural or legal person, society or the state" ${ }^{" 13}$. According to the specified norm the sign causing existence of structure of crime is absence of public danger of the committed.

It should be noted that articles 36-43 of the criminal code of Ukraine provide for circumstances precluding the criminality of the act, which contains signs precluding the presence of a crime.

In blank dispositions of articles of a Special part of UK or signs of structure of a crime are not specified, or are covered, but not all. They are defined in whole or in part in other (not criminal) laws or other normative legal acts of Ukraine or international treaties, references to which are in the dispositions of the above ${ }^{14}$.

Signs of corpus delicti in its significance can be divided into two groups: 1) positive 2) negative. The first group includes signs indicating the presence of a crime, and the second-its absence. Such terminological name signs offered exclusively from the point of view of their influence on the presence or absence of crime, because with a General social position, their values are diametrically opposed: positive, that is acceptable, are those signs that indicate a lack of evidence and negative, that is unacceptable in his presence.

If you carefully read the dispositions of the articles of the Special part of the criminal code of Ukraine, you can understand that there are more positive signs than negative ones. According to the degree of public danger signs of a crime are divided into the following groups: constitutive - is inherent in both the basic and the qualified and preferred offences (article 66 and 67 of the criminal code); qualified - signs which constitute aggravating circumstances included in the offense (article 67 of the criminal code); preferred characteristics are extenuating circumstances (article 66 of the criminal code).

Aggravating and mitigating circumstances are, respectively, qualified and privileged features. However, the latter do not affect the qualification of the crime, but are taken into account only in the case of sentencing.

For gnoseological, essence signs can be divided into two groups: objective-signs that characterize the object and the objective side of the crime; subjective-the subject and the subjective side of the crime.

Academician V. Kudryavtsev proposes to divide the signs of the crime by the criterion of certainty. In his opinion, the signs of a crime can be divided into: certain-signs, the content of which is disclosed by the legislator is not

\footnotetext{
${ }^{13}$ Ukrainian criminal code. P. 53-62.

${ }^{14}$ Sukhonos V. Criminal law. The General part of: the textbook / Sukhonos V., A. Klochko, R. Belokon ; for zag. Sukhonos V. Summa, 2015. P. 62-65.
} 
included in the law; evaluation signs, the content of which is not disclosed, but is largely determined by the consciousness of the lawyer applying the law, taking into account the requirements of the criminal code and the circumstances of a particular.

Agreeing with the given definition of estimated signs, it would be desirable to object to the author of the specified work where he carries estimated signs to one of varieties of variable signs ${ }^{15}$ as, first, estimated and variable signs are independent and various legal categories, and, secondly, the essence of estimated signs does not change during action of the concrete criminal law. A lawyer discloses their content subjectively, according to his experience and legal knowledge, as well as adherence to a particular theoretical concept of criminal law, interests, etc. In addition, therefore, can be RES-Nay. Therefore, according to the degree of constancy, the signs of the crime should be divided into two groups: permanent - their content remains unchanged for the entire time of the criminal law and does not depend on the circumstances of the crime; non - permanent (variable) - the content can be changed without changing the text of the disposition of a particular article of the Special part of the criminal code of Ukraine ${ }^{16}$.

In our opinion, giving the characteristics of intermittent signs of a crime, there are two of them: 1) blanket - that is, as already mentioned, the features provided in other (non-criminal) laws, other legal acts or international treaties of Ukraine, links to which are provided in the blank in dispositions of articles of the Special part of criminal code of Ukraine and 2) the signs experiencing due to changes in norms of General part of the criminal code of Ukraine.

In the legal literature (mainly in Russia) it is proposed to divide the signs of the crime according to the specifics of the terminological definition in the law, that is, descriptive. It is impossible to agree with such statement as in the description division of signs on such which are defined is supposed: a) common terms (for example, the state or personal property); b) scientifically-theoretical terms (for example, epizootics), c) special legal terms (for example, plunder) ${ }^{17}$.

It should be noted that in the above classification system of signs of the crime, any sign has its place in each classification group. For example, someone else's property as the subject of the offense is an optional sign, and as a subject of theft under articles of section 6 of the criminal code of Ukraine - obligatory sign of structure of a crime and is seen as a sign: which

\footnotetext{
${ }^{15}$ Brainin M. Criminal law and its application. Moscow: Legal literature, 1967. P. 59-63.

${ }^{16}$ Sukhonos V. Criminal law of Ukraine. General part: textbook / V. V. Sukhonos. Sumy: University book, 2016.

${ }^{17}$ Naumov V. Russian criminal law. Common part. Course of lectures. Moscow: BECK, 1999. P. 154.
} 
provides a specific article of the Special part of the criminal code of Ukraine; positive; behavior; objective; determined; constant; as described in the criminal law commonly used term.

Depending on the reflection in the criminal law-articles of the special part of the criminal code of Ukraine-the elements of the crime are classified on three grounds: the degree of public danger; the method of description; design features.

According to the degree of public danger, the elements of crimes are divided into three types: basic; qualified; privileged $^{18}$.

\subsection{Axiological paradigm of the crime}

The meaning of the crime is diverse. It is not equally applied to the specific crime and to the General concept of the crime. The concrete structure of a crime has practical value, and the General concept of structure of a crimeis fundamental-applied, theoretical-practical. In addition, the specific composition of the crime has both General social and criminal-legal significance. The General social significance is manifested in the fact that in the aggregate of signs that form a specific crime, the negative assessment of society, the state and the law of the relevant behavior of the subject is highlighted, that is, the presence of the crime is a prohibitive norm. it can still be defined as the antinorm in the behavior of a member of society ${ }^{19}$.

The meaning of a particular crime is determined by the following: a) it is, as a rule, the legislative basis for the criminal-legal assessment of the committed act, namely: the qualification of the crime. The concrete structure of a crime can be called a standard with which signs of the committed act are compared; b) plays the main role in the process of qualification of a crime. The practical worker who is carrying out this process, compares signs of actually made act with the corresponding signs of concrete structure of a crime and, in such a way chooses the necessary norm of UK of Ukraine which forbids to make it; c) the correct, according to the law definition of concrete structure of a crime and all its signs provides exact qualification of a crime, that is such which the practical worker perceives as result because gives the chance to compare the specified signs with signs of actually committed act, to establish and legally fix conformity between them; d) establishment of identity, on the one hand, signs of concrete structure of a crime and, on the other - signs of actually committed act, guarantees to the subject who committed a crime, to demand to qualify its acts precisely with article of UK

${ }^{18}$ Kudryavtsev V. General theory of qualification of crimes / V. Kudryavtsev. - Moscow: Legal literature, 1972.

${ }^{19}$ Mychko N. Criminal law of Ukraine. Donetsk, 2006. P. 95. 
of Ukraine; e) establishment of concrete structure of a crime and all its signs is a prerequisite of the principle of legality during carrying out quicklyinvestigative actions and judicial proceedings at application of criminal-legal norms in practical activity ${ }^{20}$.

It should also be noted that the value of the General concept of a crime due to the relatively wide range of factors, namely: a) legal structure of any particular crime patterns and a build like this composition as a whole and each of its components and characteristics reflects the overall concept of the offense; b) the investigated concept is a theoretical basis of a specific corpus delicti, its elements and signs, because their inherent concentrates on General and specific; c) a General understanding of structure of a crime is a scientific basis, the Foundation of in-depth, specific knowledge of each of the elements of all specific offences; g) the notion is a methodological prerequisite of rational studying and learning the essence of certain specific offences, their elements and characteristics; d) this concept is a scientific basis, which ensures the formation and implementation of the intellectual component of qualified and civilized law-making that is implemented as in the definition, the formulation of criminal law norms and their improvement; e) in practice, the General concept of the corpus delicti is a theoretical prerequisite to understand the meaning of a particular corpus delicti, its elements and features in the application of criminal law ${ }^{21}$.

It should be noted that in the science of criminal law, the qualification of crimes is considered and investigated in relation to the qualification of certain types of crimes (for example, against property, the environment, etc.), which is the subject of study of a Special part of criminal law. The value of qualifications is diverse. Indeed, the establishment in the act of signs of a crime is achieved only by qualification, which is the legal basis for bringing a person to criminal responsibility, the use of procedural coercion, i.e., the legal basis for criminal responsibility and punishment of the person who committed the crime or his release from criminal responsibility and punishment. Thus, the qualification of the crime reflects not only protective criminal-legal relations, but also related with them criminal-procedural and criminalExecutive relations. Therefore, the correct qualification of crimes is the observance of the principle of legality in the activities of law enforcement agencies and the court. In addition, it should be noted that the correct qualification of the crime is of important criminological importance, because

${ }^{20}$ Sukhonos V. Criminal law of Ukraine. General part: textbook / V. V. Sukhonos . Sumy: University book, 2016. P. 46-55.

${ }^{21}$ Sukhonos V. Criminal law of Ukraine. General part: textbook / V. V. Sukhonos. Sumy: University book, 2016. 
on its basis the qualitative structure of crime is manifested and measures to combat it are developed. If the qualification is wrong, it will not give a real picture of the state and dynamics of crime, which will lead to errors in planning the fight against crime.

Qualification of a crime is also important for law-making work, because successes or difficulties in qualification show the legislator the degree of law enforcement effectiveness of certain criminal law norms and can be the basis for their changes or additions ${ }^{22}$.

Given allows to conclude about the importance of specific categories of crime and the General concept of a crime for law-making and law enforcement practice and theory of criminal law.

\section{CONCLUSIONS}

It is known that the fight against crime in all its forms in recent years has increasingly attracted the attention of legal scholars. Criminological science considers the issues of combating crime in a single context with other social problems associated with the further development of economic relations in Ukraine and improving the living standards of the population of the state. For this purpose it is necessary to ensure effective improvement of planning and development of complex programs on the most important scientific, technical, economic and social problems. Crime also belongs to the latter category. In Ukraine, there is an increase in organized crime and corruption, it is a complex social phenomenon. Criminal law is an instrument of social policy, but it cannot be a universal, basic, most effective means of combating crime. And in some cases, it simply cannot eradicate, for example, corruption phenomena.

Despite the above, it should be noted that the correct qualification of crimes is important for law enforcement officials and the court. No wonder the criminals by hook or by crook mislead these bodies to avoid responsibility. Therefore, the ability to correctly and quickly qualify the crime, that is, to make a choice of criminal law, accurately reflecting the actual circumstances of the case, allows to distinguish the criminal act from the non-criminal; to give them a legal assessment in accordance with the law; to determine those facts, which reflect the characteristics of the offense and must be proved in the manner specified by the criminal procedural legislation (UPK), which will make it possible in future to promptly gather evidence and secure the material, which confirms the Commission of a crime guilty. So, due to the fact that, on the one hand, the possibilities of the criminal law are

\footnotetext{
${ }^{22}$ Naumov V. Russian criminal law. Common part. Course of lectures. Moscow: BECK, 1999. P. 154.
} 
objectively limited by it to the established principles, as we wrote above, and on the other - the procedural framework of proof, it is not entirely justified to link the increase in the effectiveness of the fight against crime in the first place with changes in criminal legislation. However, it is adopted in order to contribute as much as possible to the solution of this problem. In conclusion, I would like to draw the attention of practitioners and scientists that from the point of view of criminal law, this will always be a fight not "in General" against crime, including organized, corruption-related, but with specific manifestations of socially dangerous behavior of subjects; not with phenomena in General, but with personalized excesses of representatives of criminal organizations, corrupt officials, individual criminals. Therefore, we believe that the task of the science of criminal law and criminology is to continue the study of these negative phenomena, to accurately determine the boundaries of the criminal-legal struggle against them, despite the obstacles created by persons interested in corruption.

\section{SUMMARY}

In the article based on modern achievements of the theory of criminal law the Institute of corpus delicti is investigated. Attention is paid to both axiological and epistemological aspects of the crime, its structure and theoretical and practical aspects of implementation are considered.

\section{REFERENCES}

1. Criminal law of Ukraine: General part: textbook / Y. Baulin, V. Borisov, V. Tyutyugin, etc.. The 4th form., rewritten. and extra. Kharkiv: Pravo, 2010. P. 94.

2. Kudryavtsev V. the General theory of qualification of pre-steps. Moscow: Yuridicheskaya Literatura, 1972. P. 8;

3. Kurinov B. Scientific bases of qualification of crimes. Moscow: Moscow state University, 1984. P. 20.

4. Ukrainian criminal code. Sumy: LLC “GDP Nostis”, 2015.

5. Sukhonos V. Criminal law of Ukraine. General part: textbook / V.V. Sukhonos . Sumy: University book, 2016. P. 46-55.

6. Code of Ukraine on administrative offences. URL: http://zakon3.rada.gov.ua/laws/show / 80731-10.

7. Ukrainian criminal code. Sumy: LLC “GDP Nostis”, 2015. P. 183.

8. Ukrainian criminal code. Source: LLC "GDP NOTIS”, 2015. P. 55.

9. Ukrainian criminal code. Sumy: LLC “GDP Nostis”, 2015. C. 9.

10. Halabala M. Criminal-legal science of independent Ukraine. Problems of the General part : the textbook / M. Halabala. Kyiv: Yurinkom Inter, 2013. P. 37-74. 
11. Criminal law. General part : the textbook / OTV. edited By I. Kozachenko and Z. Neznamova. Moscow: Norma, 1997. P. 114.

12. Criminal law, General part, textbook ed. Kharkiv: Pravo, 2010. P. 85.

13. Mychko N. Criminal law of Ukraine. Donetsk, 2006. P. 95;

14. Gonchar T., Streltsov, E., and such famous O. Criminal law of Ukraine. General and special parts 6 tutorial. Kharkiv: Odyssey, 2013. P. 29.

15. Sukhonos V. Criminal law of Ukraine. General part: textbook / V.V. Sukhonos. Sumy: University book, 2016. P. 59-65.

16. Ukrainian criminal code. P. 53-62.

17. Sukhonos V. Criminal law. The General part of: the textbook / Sukhonos V., A. Klochko, R. Belokon ; for zag. Sukhonos V. Summa, 2015. P. 62-65.

18. Kudryavtsev V. General theory of qualification of crimes / V. Kudryavtsev. - Moscow: Legal literature, 1972.

19. Brainin M. Criminal law and its application. Moscow: Legal literature, 1967. P. 59-63.

20. Sukhonos V. Criminal law of Ukraine. General part: textbook / V.V. Sukhonos. Sumy: University book, 2016.

21. Naumov V. Russian criminal law. Common part. Course of lectures. Moscow: BECK, 1999. P. 154.

Information about the author: Klyuev O. M., Doctor of Law, Professor, Director of the Kharkiv Scientific Research Institute of Forensic Examinations N.A. Prof. M. S. Bocarius of the Ministry of Justice of Ukraine 8-A, 49 Zolochivska str., Kharkiv, 61177, Ukraine 